UDC 61

\title{
EFFORTS TO CHANGE THE LIFE STYLE AFTER PERCUTANEOUS CORONARY INTERVENTION: PATIENTS' PERSPECTIVE
}

\author{
Baroroh Dewi Baririet ${ }^{\star}$, Ratnawati Retty, Astari Asti Melani \\ Faculty of Medicine, University of Brawijaya, Indonesia \\ *E-mail: putrisejuk@gmail.com
}

\begin{abstract}
Patient who had Percutaneous Coronary Intervention (PCI) need postoperative care. The postoperative care should be given continually and it demands awareness and compliance from patients in managing their lifestyle. This process often gives the patients various obstacles and challenges. This study explored patients' experiences in performing their daily life activities after they had percutaneous coronary intervention. The study was conducted by applying a phenomenology qualitative approach, involving 7 participants who had received $\mathrm{PCl}$ therapy and fulfilled the predetermined criteria. In-depth semi-structured interviews were conducted. The data were analyzed using an Interpretative Phenomenological Analysis. The revealed theme was related to the struggle to modify their lifestyle. This theme described how participants tried to change their habit, including their exertion and feeling during their everyday life. This theme was divided into 6 sub-themes. Patients who had PCl experienced various psychological, physical and social issues during their effort to endure lifestyle changes. Continuous accompaniment, counseling and appropriate information in maintaining their lifestyle, helped the patients to cherish their life and motivated them to exchange their lifestyle better.
\end{abstract}

\section{KEY WORDS}

Lifestyle, patients activity, patients' feeling, coronary angioplasty, coronary stent.

Coronary heart disease (CHD) is the leading cause of death in global, regional and local. The World Health Organization in 2014 stated that 17.5 millions people all over the world died from cardiovascular diseases, which made up to $31 \%$ out of 56.5 millions rate of mortality in the world (WHO, 2014). The Result of Primary Health survey (Riset kesehatan Dasar /Riskesdas) identified CHD in the third leading cause of death in Indonesia, and it is known that CHD mostly occurred in people aged between $65-74$ years (3.6\%), followed those aged above 75 years (3.2) (Badan Penelitian dan Pengembangan Kesehatan, 2013).

$\mathrm{CHD}$ often leads to death when proper treatment is not given immediately within the emergency phase which is called Acute Coronary Syndrome (ACS) (O'Keefe-McCarthy et al., 2014; Torry, Panda, \& Ongkowijaya, 2014). In ACS, there is a part of heart that lacks of blood supply due to blockage in the coronary artery vessels (Thompson, 2013; Timmis, 2015). The statistic data released by AHA shows that in the US, a new ACS case occurs in every 25 seconds, and every 60 seconds, 1 person died ACS (Benjamin et al., 2017).

Percutaneous Coronary Intervention (PCl) is a non-surgical therapy as foremost therapy for treating ACS which aim is removing the blockage in the coronary artery vessels in order to restore the blood flow (Amsterdam et al., 2014; Levine et al., 2011; O'Gara et al., 2013; PERKI, 2015). Patients who undergo PCl usually have low and slope to stable intensity of angina, minimum of physical limitation, worthy satisfaction upon the therapy and obtain better quality of life compared to other therapies, such coronary artery bypass graft surgery(Kolh et al., 2014; Kureshi, Jones, Buchanan, Abdallah, \& Spertus, 2014). . On the other side, the possibility of restenosis and complication should be put in the top concern as possible causes of another blockage, which leads to the need of pertain another $\mathrm{PCl}$ (Amsterdam et al., 2014; Jukema, Verschuren, Ahmed, \& Quax, 2012; Kolh et al., 2014; Parasca et al., 2016; Przybysz-Zdunek, Ploch, Pluta, Dada, \& Opolski, 2012; Stolker et al., 2012). 
There are various physical and psychological changes in patients after $\mathrm{PCl}(J o h n m a n$, Mackay, Oldroyd, \& Pell, 2013; Kahkonen, Saaranen, Lamidi, Miettinen, \& Kankkunen, 2017; Kureshi et al., 2014; Zhang, 2015). Furthermore, patients' need following treatment after PCl to prevent restenosis (re-blockage) and complication. The postoperative care includes; compliance taking the drug, taking control regulary, changes in life style (including smoking cessation, dietary management, physical exercises enhancement, heart rehabilitation, fulfilment secondary treatment and re-assessment risk factor of arrhythmia and heart failure (Anderson et al., 2017; Mosleh \& Darawad, 2015; O'Gara et al., 2013; Vieira, Nobre, \& Silveira, 2016; Yang et al., 2017).

$\mathrm{PCl}$ postoperative care is a continuous treatment management that takes patients' awareness and compliance in directing their daily life. Problems might appear during the process. As the process itself is a new challenge for the patients. Unfortunately, literature on patients' condition after PCl in Indonesia is still limited. The objective of this research is to explore the patients' experience to spend their daily life after undergoing the $\mathrm{PCl}$ therapy. The result of this research is expected to provide comprehensible explanation about patients' condition after $\mathrm{PCl}$, to be used as reference in giving appropriate treatment

\section{METHODS OF RESEARCH}

This research was conducted using a qualitative phenomenological research and interpretative phenomenology as a framework. This framework is used to gaining how people perceive their everyday life. (Larkin \& Thompson, 2012).

Table 1 - Participants' Characteristics

\begin{tabular}{|c|c|}
\hline Characteristics & Total $(n=7)$ \\
\hline \multicolumn{2}{|l|}{ Sex } \\
\hline Male & 6 \\
\hline Female & 1 \\
\hline \multicolumn{2}{|l|}{ Age } \\
\hline$\leq 56$ years old & 4 \\
\hline$>56$ years old & 3 \\
\hline \multicolumn{2}{|l|}{ Religion } \\
\hline Islam & 7 \\
\hline \multicolumn{2}{|l|}{ Marital Status } \\
\hline Married/spouse is alive & $7 / 7$ \\
\hline \multicolumn{2}{|l|}{ Education } \\
\hline Primary level & 2 \\
\hline Secondary Level & - \\
\hline High school level & 2 \\
\hline Bachelor & 2 \\
\hline Master & 1 \\
\hline \multicolumn{2}{|l|}{ Employment Status } \\
\hline Employed & 3 \\
\hline Unemployed & 4 \\
\hline \multicolumn{2}{|l|}{ Status of Residence } \\
\hline Spouse & 1 \\
\hline Spouse and children & 1 \\
\hline Relatives aged $>15$ years & 5 \\
\hline \multicolumn{2}{|l|}{ Time of Ring Installation } \\
\hline Mean & 20.4 months \\
\hline Range & 1 up to 76 months \\
\hline \multicolumn{2}{|l|}{ The Frequency of $\mathrm{PCl}$} \\
\hline 1 time & 4 \\
\hline 2 times & 3 \\
\hline \multicolumn{2}{|l|}{ Type of PCl } \\
\hline Stent & 7 \\
\hline Balloon & - \\
\hline
\end{tabular}


This research involved 7 participants who fulfilled the predetermined inclusion criteria including: (1) participants have passed 4 weeks after they received $\mathrm{PCl}$; (2) participants were patients of University of Muhammadiyah Malang Hospital (UMM Hospital) Indonesia; (3) participants reside in Malang, and (4) participants were able to communicate using Javanese and Indonesian languages and (5) participants were willing to participate in this study by signing the consent. Patients' characteristics are presented in Table 1.

This research has received an ethical approval as stated in the letter of research ethics Number. 35/EC/KEPK-S2/02/2018 issued by the Research Ethics Committee (Komisi Etik Penelitian Kesehatan) of Universitas Brawijaya located in Malang City, Indonesia.

After the data had been collected through medical records, the researchers tried to contact with every participant candidate in order to give them thorough information and to obtain their consent. Researcher contacted the participant via short message, telephone call and home visit. The researcher also tried to manage rapport with participant $s$ through home visit before and after the interview. Interviews were conducted in certain time and location as agreed by participants and researcher. Before the interviews were started, participants had been told about the process of the interview and asked for patients' permission to record the conversation

Research data were collected using in-depth interview to explore participants' daily life and their emotional responses after undergoing $\mathrm{PCl}$ therapy. The interviews were administered in a semi-structured using interview guideline. The researcher also tried to stay focus in every sentence spoken by the participant and maintain the awareness upon every change that occurred in the process of interviews. In addition, the researcher was also aware of diverse changes or condition around the participants that might influence their responses. Furthermore, the researchers also tried to check any unanswered item to be later re-asked to the participants. During the interview, the researcher also underlined some important points stated by the participants which might need further explanation.

An interview with the first participant was conducted after the exercise which is held by Klub Senam Jantung (Healty Heart Community) of UMM Hospital in the parking area of UMM hospital. Whereas, the other participants were interviewed at home, where they were accompanied by their family, either husband/wife or children. The interview was done from March $5^{\text {th }}$ until March $28^{\text {th }}$. The duration of each interviews differs, ranging from 32 to 84 minutes and the average duration was around 63 minutes. The recording of the interviews were then transcribed prior to the implementation of Interpretative Phenomenological Analysis (IPA) (Larkin \& Thompson, 2012).

\section{RESULTS OF STUDY}

This research developed a theme "the struggle to modify their lifestyle. The theme was divided into 6 sub-themes. The theme describes participants' effort in changing their unhealthy life style, including their attempts and their feelings towards their daily life.

Trying to restraint their self through better lifestyle. This sub-theme describes participants' comprehension about activities that should be conducted after PCl. Most of the participants explained that they were required and tried hard to conform the life style as proposed: "it should be...we should be learn to discipline. Discipline makes daily activity as routine, as automatically doing by us. For the first time, it is hard, but if we have strong motivation, it will changes from doing certain activity to stop those activity. Finally, my mind is full of this understanding. Any way, we can learn from the compliance, as we do it as routine, it becomes automatic"(P2, line 220).

As seen from the transcription, participants mentioned two key words; learning which refers to training and discipline which means being obedience to the rules (Badan Pengembangan dan Pembinaan Bahasa, 2016). Participants stated that the self-discipline process that is done continuously will construct new habit. In this phase, the burden will be lessen as they get accustomed to live a better life style. The strong will to be healthy made it easier for the participants to stay discipline in living a better life style. They were reluctant 
and forced to change the habit at first, but gradually they grew awareness to change their unhealthy habit with a healthier one.

Striving Healthy Dietary Habits. This sub-theme taps on participants' experience in controlling their dietary habits.

Firstly, participants fasted to control their dietary: "I, $m m m m$....Ihold myself back, , I hold back by fasting. Fasting (in Islam) every Monday and Thursday, actually controlled myself, because my diabetes only 135-145. Whereas I am not fasting, my blood glucose is up from 170." (P2 line 116).

The fasting was done by not eating food or drinking any water in purpose, and usually fasting is closely related to obligations in some religions (Badan Pengembangan dan Pembinaan Bahasa, 2016). Participants stated that fasting successfully maintained their glucose level at the ideal level and made their body felt healthier.

Second, participants tried to resist the urge to eat their favorite food to keep their dietary healthy. This statement was expressed as follows.

"In the past, when I want to eat delicious food as "pangsit" (noodles)... immediately, set...set...I go to those eatery which sell my favourite noodles.... And soon after I invite my family, I told them that noodles in this eatery is tasty. Another chance, I found scrumptious meatballs, then I told my family again and invite them to eat this meatballs. However, after I am ill, whether I know there is something delicious, I pretend not knowing, I go straight through the street" (P2, line 126).

The word "pretend", implying that the participants tried to act as if not knowing that their favorite food were there (Badan Pengembangan dan Pembinaan Bahasa, 2016). This reflects behavioral change in dealing with favorite food. They used to simply eat their food, yet they are now aware of the risk that might be caused by the food for themselves and their health. Thus, they ignored the food by pretending not to recognize the presence of the food around them. In the other sentence, they tried to convince their mind that they already know the taste of the food as they used to eat them, and now they do not have to eat them anymore.

Third, participants selected their dietary menu. They no longer consume rice for breakfast and dinner as recommended by their physicians.

"We are recommended by doctors $N V$, not to eat rice in the breakfast and dinner. ....and I do this recommendation" (P1, line 41).

Participants also stated that they no longer consume fast food. They prefer eating homemade food. They also eat their food in small serving, with higher portion of vegetables than the rice or the side dish. In addition, they only consume lean meat, and they avoid eating Padang cuisine that contains too much coconut milk.

Fourth, they avoid eating prohibited food. They tried to avoid eating various food that contain high gases such as mustard plant and cabbage.

"It is convinced, there is some prohibition. Such as sawi...hmmm....because containing...hmm ... what is that...hmm... Containing gases..." (P5, line 148).

"If we cook vegetable soup, the important thing is not acquiring cabbage as ingredients. Because something contains gases as cabbage, is disallowed..." (P6, line 250).

The word "prohibition" means proscription or ban something from happening (Badan Pengembangan dan Pembinaan Bahasa, 2016). Participants said that gases makes their stomach fell uncomfortable.

Attempting Mind Management. In this section, participants share their experience in managing their mind, directing their mind to focus on their condition and their health. They told the researcher about spiritual activities that they do to keep their mind in the positive circumstances.

"Bismillah (In the name Of Allah)..., I read Qur'an (holy book of Muslim) every time I could. I keep my heart unruffled with Qur'an. I maintain the calmness with Qur'an. Sometimes I reciting some surah which I memorize well, such Surah Yasin, Surah Al Mulk, Surah Al Waqiah, Surah Ar Rahmaan. Everday I recite it, so my mind keep clear without having hard time to have negative thingking. I just read, that's it miss, I calm myself down by reading, I make my heart calm my own, by reading to the best that I can, anything, yasin and 
tabarok, waqi'ah, ar-rahman, that's it everyday, so I will not have any bad thoughts." (P7, line263)

The word "read" means Qur'an recitation. They stated that they often recite short Surah in Al-Quran such as Yasin, Al Mulk, Al Waqi'ah, and Ar-Rahman. They recite the verses to calm down their heart and feeling, therefore preventing them from having negative thoughts about future. Other participants also regularly attend held by preacher to nurture their awareness that every single thing that happens in this world is by God's will and God will always show the best path to take.

They also intensify the frequency of meeting other people prevent them from having bad judgments. They explained that if they stay alone in their rooms, they tend to grow anxiety about their health condition.

Endeavour the smoking cessation. This section presents participants' attempt to avoid smoking cigarettes even when they want to: "indeed... I should stay in the bedroom, because in th bedroom, we could not smoke, so, I stay in the bedroom...." (P1, line 149). "hmm......reading a book, watching television, operating computer...that's all...." (P1, line152). "so, the cigarette only....puffftt..... because I have a lot of friends who smoke while we are sit around... and when I want to smoke because they are smoking, I am smoke like this, without lighted (P4, line144).

The key words found in those three phrases explicitly explain participants' attempts to avoid smoking. At home, they are asked by their family members to stay in non-smoking area as agreed by the whole family such as bedroom. They also keep themselves busy doing various activities to distract their mind such as reading books, watching television, and using computers. Besides, participants also explained some time when they really wanted to smoke, they held the cigarette on hand and pretending to smoke it without lighting it up.

Trying to do exercises. Participants described the physical exercises that they usually do. Most of them prefer doing cardiac exercises as a part of their physical exercises.

"Yeah, I still played tennis in 56, then I quitted as I entered 70, now I do cardiac exercise", (P1, line 20).

Other participants preferred walking outside the house or inside the house. They usually walk for a varied duration and time depending on their leisure time.

"Here I still do exercise, I do morning walk, I force myself to do it twice a week, even just for half an hour", (P3, line 35).

".I walk at home, take some steps", (P6, line 128).

"I do exercise like walking. I walk just around here", (P4, line 138).

Feeling burdened by the new life style they have to develop. This sub-theme describes how participants feel drained by daily life that should be adopted. They actually dislike the prohibition in doing activities they want to do.

"Talking about sadness, I am sad because of the prohibition", (P3, line 47) line 210)

"It all depends on myself, all of those prohibition I should comply them my own.", (P3,

They expressed their sad feeling about the activity prohibition, although they alert themselves not to do it.

"It is hard to take the medicine, if I may request, I would not want any of them. I can take it regularly in the morning, but in the evening, I sometimes miss it"( $P 3$, line 221).

"The most difficult thing is to be complient, it is burdensome since I often forget, while the drug should be really taken in an indeed, really ...., (P4, line 53.)

Participants also expressed their reluctance in taking their medicine. They find it difficult and burdensome to take the medicine regularly. Those two key words refer to the same meaning of "difficult" (Badan Pengembangan dan Pembinaan Bahasa, 2016). The difficulty might appear as they often forget to take their medicine on time. Even more, due to this difficulty, they made a request for their physicians not to give them many kinds of medicine.

The combination of the feeling difficult, hard, and sad is best described by the term "tortured". Participants often feel tortured by the treatment that they have to go through. They 
have tried to do various attempts within their sick condition, which describe their efforts in modifying their life style.

\section{DISCUSSION OF RESULTS}

This paper explains patients' effort and difficulties during their attempts to change their daily life. This theme is worth researching as not every patient is aware upon the menaceof unhealthy lifestyle and willing to change it to a better one. Patients who have undergone $\mathrm{PCl}$ often experience various physical and psycho-social changes (Johnman, Mackay, Oldroyd, \& Pell, 2013; Kahkonen et al., 2017; Kureshi et al., 2014; Zhang, 2015). The changes demand the patients to adapt to the new situation in order to be able to do daily activities and improve their quality of life. However, some patients find it difficult to adapt to the condition due to the lack of information and family or social support (O'Gara et al., 2013; Vieira et al., 2016). It is considered necessary to provide patients with appropriate and accurate information related to the plan of postoperative care after PCl (Anderson et al., 2017; Windecker et al., 2014; Zellweger et al., 2003). It is expected that the explanation lessens patients' burden in preparing their life after the treatment.

The result of this research showed various efforts made by participants in changing their life style. Participants modify their dietary habit, manage their mind, perform more physical activities and exercise and decrease their frequency of smoking. In another qualitative research, it is also stated that some patients explained their effort in controlling their dietary and taking their medicine on time (Dullaghan et al., 2014; Hasankhani et al., 2014). The success of patients' efforts is determined by a number of factors, including how patients perceive health, their religious beliefs, the types of therapy, patients' knowledge, medical services and the social economic condition of the patients (Rafii, Fatemi, Danielson, Johansson, \& Modanloo, 2014).

The treatment after $\mathrm{PCl}$ must be done continuously and it demands patients' awareness and discipline in controlling their life style. Inadequate treatment decreases patients' quality of life after undergoing the $\mathrm{PCl}$ treatment. Various issues often occur during the after treatment of $\mathrm{PCl}$ including; the level of patients' awareness to stay discipline performing a healthy life style, problems related to the accessibility to regional health facility, disobedience in taking antithrombotic medication, the presence of vascular trauma from $\mathrm{PCl}$, inadequate prevention upon the factors that cause health deterioration, and patients' social economic condition (Kämpfer et al., 2017; O'Gara et al., 2013).

\section{CONCLUSION}

The result of this research describes patients' effort in changing their life style in order to improve their health. This research also explains patients' feelings when they are required to change their life style. This research has provided insights that might be useful for medical personnel, especially nurses in taking care of patients after $\mathrm{PCl}$. This research shows that patients who have undergone $\mathrm{PCl}$ experience massive dynamicity that involves not only their psychological aspect, but also their physical and social aspects in accomplish their life style. Adequate attention, counseling, and information about the postoperative care of $\mathrm{PCl}$ help the patients maintain positive attitude that motivates them to change their unhealthy life style to a healthier one.

\section{REFERENCES}

1. Amsterdam, E. A., Wenger, N. K., Brindis, R. G., Casey, D. E., Ganiats, T. G., Holmes, D. R., ... Zieman, S. J. (2014). 2014 AHA/ACC Guideline for the Management of Patients With Non-ST-Elevation Acute Coronary Syndromes. Circulation, 130(25), e344 LP-e426. Retrieved from http://circ.ahajournals.org/content/130/25/e344.abstract

2. Anderson, L., Brown, J. P. R., Clark, A. M., Dalal, H., Rossau, H. K., Bridges, C., \& Taylor, R. S. (2017). Patient education in the management of coronary heart disease. 


$$
\text { Cochrane Database of Systematic Reviews, }
$$

https://doi.org/10.1002/14651858.CD008895.pub3

3. Badan Penelitian dan Pengembangan Kesehatan. (2013). Riset Kesehatan Dasar (RISKESDAS) 2013. Laporan Nasional 2013, 1-384. https://doi.org/1 Desember 2013

4. Badan Pengembangan dan Pembinaan Bahasa. (2016). KBBI $\vee 0.2 .0$ Beta (20). Kementerian Pendidikan dan Kebudayaan Republik Indonesia. Retrieved from https://kbbi.kemendikbud.go.id/

5. Benjamin, E. J., Blaha, M. J., Chiuve, S. E., Cushman, M., Das, S. R., Deo, R., ... American Heart Association Statistics Committee and Stroke Statistics Subcommittee. (2017). Heart Disease and Stroke Statistics-2017 Update: A Report From the American Heart Association. Circulation, 135(10), e146-e603. https://doi.org/10.1161/cir.0000000000000485

6. Dullaghan, L., Lusk, L., McGeough, M., Donnelly, P., Herity, N., \& Fitzsimons, D. (2014). "I am still a bit unsure how much of a heart attack it really was!" Patients presenting with non ST elevation myocardial infarction lack understanding about their illness and have less motivation for secondary prevention. European Journal of Cardiovascular Nursing: Journal of the Working Group on Cardiovascular Nursing of the European Society of Cardiology, 13(3), 270-276. https://doi.org/10.1177/1474515113491649

7. Hasankhani, H., Gholizadeh, L., Mohammadi, E., Zamanzadeh, V., Allahbakhshian, A., Ghaffari, S., \& Allahbakhshian, M. (2014). The lived experiences of patients post coronary angioplasty: A qualitative study. Journal of Vascular Nursing, 32(4), 144-150. https://doi.org/https://doi.org/10.1016/j.jvn.2014.04.001

8. Johnman, C., Mackay, D. F., Oldroyd, K. G., \& Pell, J. P. (2013). Quality of life following percutaneous coronary interventions in octogenarians: a systematic review. Heart, 99(11), 779. https://doi.org/http://dx.doi.org/10.1136/heartjnl-2012-303353

9. Jukema, J. W., Verschuren, J. J. W., Ahmed, T. A. N., \& Quax, P. H. A. (2012). Restenosis after PCl. Part 1: pathophysiology and risk factors. Nature Reviews. Cardiology, 9(1), 53-62. https://doi.org/http://dx.doi.org/10.1038/nrcardio.2011.132

10. Kahkonen, O., Saaranen, T., Lamidi, M.-L., Miettinen, H., \& Kankkunen, P. (2017). Perceived Health among Patients with Coronary Heart Disease Four Months after a Percutaneous Coronary Intervention. International Journal of Caring Sciences, 10(1), 5466. Retrieved from https://search. proquest.com/docview/1896832838?accountid=46437

11. Kämpfer, J., Yagensky, A., Zdrojewski, T., Windecker, S., Meier, B., Pavelko, M., ... Saner, H. (2017). Long-term outcomes after acute myocardial infarction in countries with different socioeconomic environments: an international prospective cohort study. BMJ Open, 7(8). Retrieved from http://bmjopen.bmj.com/content/7/8/e012715.abstract

12. Kolh, P., Windecker, S., Alfonso, F., Collet, J.-P., Cremer, J., Falk, V., ... Juni, P. (2014). 2014 ESC/EACTS Guidelines on myocardial revascularization: The Task Force on Myocardial Revascularization of the European Society of Cardiology (ESC) and the European Association for Cardio-Thoracic Surgery (EACTS) Developed with the special contribution . European Journal of Cardio-Thoracic Surgery: Official Journal of the European Association for Cardio-Thoracic Surgery, 46(4), 517-592.

13. Kureshi, F., Jones, P. G., Buchanan, D. M., Abdallah, M. S., \& Spertus, J. A. (2014). Variation in patients' perceptions of elective percutaneous coronary intervention in stable coronary artery disease: cross sectional study. BMJ : British Medical Journal (Online), 349. https://doi.org/http://dx.doi.org/10.1136/bmj.g5309

14. Larkin, M., \& Thompson, A. (2012). Interpretative Phenomenological Analysis. In in A Thompson \& D Harper (eds), Qualitative research methods in mental health and psychotherapy: a guide for students and practitioners (p. 99-116.). John Wiley \& Sons, Oxford. https://doi.org/10.1002/9781119973249

15. Levine, G. N., Bates, E. R., Blankenship, J. C., Bailey, S. R., Bittl, J. A., Cercek, B., ... Ting, H. H. (2011). 2011 ACCF/AHA/SCAI Guideline for Percutaneous Coronary Intervention: Executive Summary. Journal of the American College of Cardiology, 58(24), 2550-2583. https://doi.org/http://dx.doi.org/10.1016/j.jacc.2011.08.006

16. Mosleh, S. M. (2015). Patients' Adherence to Healthy Behavior in Coronary Heart 
Disease: Risk Factor Management among Jordanian Patients. Journal of Cardiovascular Nursing, 30(6). Retrieved from http://journals.Iww.com/

17. O'Gara, P. T. et al (2013). 2013 ACCF/AHA Guideline for the Management of STElevation Myocardial Infarction: A Report of the American College of Cardiology Foundation/American Heart Association Task Force on Practice Guidelines. Journal of the American College of Cardiology, 61(4), e78-e140.

18. O'Keefe-McCarthy, S., McGillion, M., Nelson, S., Clarke, S. P., Jones, J., Rizza, S., \& McFetridge-Durdle, J. (2014). Acute Coronary Syndrome Pain and Anxiety in a Rural Emergency Department: Patient and Nurse Perspectives. CJNR (Canadian Journal of Nursing Research), 46(2), 80-100.

19. Parasca, C. A., Head, S. J., Milojevic, M., Mack, M. J., Serruys, P. W., Morice, M.-C., ... Kappetein, P. A. (2016). Incidence, Characteristics, Predictors, and Outcomes of Repeat Revascularization After Percutaneous Coronary Intervention and Coronary Artery Bypass Grafting: The SYNTAX Trial at 5 Years. JACC: Cardiovascular Interventions, 9(24), 2493-2507. https://doi.org/https://doi.org/10.1016/j.jcin.2016.09.044

20. PERKI. (2015). Pedoman tatalaksana sindrom koroner akut. Pedoman Tatalaksan Sindrome Koroner Akut, 88. https://doi.org/10.1093/eurheartj/ehn416

21. Przybysz-Zdunek, B., Ploch, M., Pluta, W., Dada, M., \& Opolski, G. (2012). All-cause readmission and repeat revascularization after percutaneous coronary intervention. Cardiology Journal, 19(2), 174.

22. Rafii, F., Fatemi, N. S., Danielson, E., Johansson, C. M., \& Modanloo, M. (2014). Compliance to treatment in patients with chronic illness: A concept exploration. Iranian Journal of Nursing and Midwifery Research, 19(2), 159-167. Retrieved from http://www.ncbi.nlm.nih.gov/pmc/articles/PMC4020025/

23. Stolker, J. M., Cohen, D. J., Kennedy, K. F., Pencina, M. J., Lindsey, J. B., Mauri, L., ... Kleiman, N. S. (2012). Repeat Revascularization After Contemporary Percutaneous Coronary Intervention. Circulation: Cardiovascular Interventions, 5(6), 772 LP-782. Retrieved from http://circinterventions.ahajournals.org/content/5/6/772.abstract

24. Thompson, P. L. (2013). Acute Coronary Syndromes: Much Progress, New Challenges. Clinical Therapeutics, 35(8), 1054-1057.

25. Timmis, A. (2015). Acute coronary syndromes. BMJ : British Medical Journal (Online), 351. https://doi.org/http://dx.doi.org/10.1136/bmj.h5153

26. Torry, S. R. V, Panda, L., \& Ongkowijaya, J. (2014). Gambaran faktor risiko penderita sindrom koroner akut. E-CliniC, 2(1).

27. Vieira, L. P. (2016). Effects of nutrition education on recurrent coronary events after percutaneous coronary intervention: A randomized clinical trial. BMC Nutrition, 2. https://doi.org/http://dx.doi.org/10.1186/s40795-016-0111-5

28. WHO. (2014). Global status report on noncommunicable diseases 2014. World Health, 176. https://doi.org/ISBN 9789241564854

29. Windecker, S., Kolh, P., Alfonso, F., Collet, J.-P., Cremer, J., Falk, V., ... Witkowski, A. (2014). 2014 ESC / EACTS Guidelines on myocardial revascularization : web addenda. European Heart Journal, 1-12. https://doi.org/10.1093/eurheartj/ehu278b

30. Yang, X., Li, Y., Ren, X., Xiong, X., Wu, L., Li, J., Xing, Y. (2017). Effects of exercisebased cardiac rehabilitation in patients after percutaneous coronary intervention: A metaanalysis of randomized controlled trials. Scientific Reports, 7, 44789. Retrieved from http://dx.doi.org/10.1038/srep44789

31. Zellweger, M. J. et al (2003). Long-term outcome of patients with silent versus symptomatic ischemia six months after percutaneous coronary intervention and stenting. Journal of the American College of Cardiology, 42(1), 33-40. https://doi.org/http://dx.doi.org/10.1016/S0735-1097(03)00557-6

32. Zhang, P. (2015). Study of Anxiety/Depression in Patients with Coronary Heart Disease After Percutaneous Coronary Intervention. Cell Biochemistry and Biophysics, 72(2), 503507. https://doi.org/http://dx.doi.org/10.1007/s12013-014-0495-2 